\title{
Correlation and Path Coefficient Analysis for Yield Contributing Traits and Grain Zinc Concentration in Biofortified Inbred Lines of Maize (Zea mays L.)
}

\author{
Priyanka Jaiswal $^{1 *}$, Banshidhar ${ }^{2}$ and Rajesh Singh ${ }^{1}$ \\ ${ }^{1}$ Genetics and Plant Breeding, I.Ag.Sc., BHU, Varanasi, UP, India \\ ${ }^{2}$ Genetics and Plant Breeding, GBPUAT, Pantnagar, Uttarakhand, India \\ *Corresponding author
}

\begin{tabular}{|l|}
\hline Ke y w o r d s \\
$\begin{array}{l}\text { Biofortified maize } \\
\text { inbred, Association } \\
\text { analysis and Path } \\
\text { analysis }\end{array}$ \\
\hline Article Info \\
\hline $\begin{array}{l}\text { Accepted: } \\
\text { 12 June 2019 } \\
\text { Available Online: } \\
\text { 10 July } 2019\end{array}$ \\
\hline
\end{tabular}

A B S T R A C T
The present investigation was undertaken with the objective to study correlation and path coefficient analysis for yield contributing traits and grain zinc concentration in 30 biofortified inbred lines of maize (Zea mays L.). Trials were conducted during kharif 2017 at Agricultural Research farm, Institute of Agricultural Sciences, BHU in Randomized Block Design with three replications. Each entry was planted in row-to-row and plant-to-plant spacing of $60 \mathrm{~cm} \times 20$ $\mathrm{cm}$. All the recommended packages of practices were followed to raise a good crop. In general, genotypic correlation coefficients were higher than the phenotypic correlation coefficients, indicating that there is strong inherent association between the various traits investigated in this work. Tassel length, ear height and plant height was positively and significantly associated with grain yield per plant and grain zinc concentration which indicates the importance of these traits in selection for high yielding inbred lines. Path analysis studies showed direct positive effect of cob diameter, tassel length, ear height, days to 50\% silking, 100 seed weight and plant height on grain yield per plant. Hence, these traits can be considered as important attributes for suitable selection criteria for both direct and indirect selection

\section{Introduction}

Maize (Zea mays L.) is one of the most important food crops grown in the world. It serves as an important human food, a basic element of animal feed and a highly demanded raw material for manufacture of many industrial products. In India, it is one of the three most important cereal next to wheat and rice and cultivated over an area of 8.69 million hectares, grains production 21.81 million tons and the average productivity $2509 \mathrm{~kg} / \mathrm{ha}$ (2015-2016, Annual report DAC \& FW). Maize kernels are good source of protein (9$10 \%)$, oil $(2.5-4 \%)$, carbohydrate $(65-70 \%)$, albuminoides $(10.4 \%)$, crude fibre $(2.3 \%)$ and ash (1. 3\%) (Cortez and Wild-Altamirano, 1972). Maize is a predominant crop in context 
of supplementing global nutrition by bridging the gap of malnutrition through "biofortification" which is a process to increase the bioavailability and the concentration of nutrients in crops through both conventional plant breeding (White and Broadley, 2008) and recombinant DNA technology (Zimmermann and Hurrell, 2002)' Yield being a complex trait is governed by a large number of genes and it depends on plant genotype and its interaction with environment (Khatab et al., 2016). The influence of each trait on yield could be known through correlation studies with a view to determine the extent and nature of relationships prevailing among yield and yield attributing traits. In general, genotypic correlation was higher than phenotypic correlation indicating a low influence of environmental factors and relative stability of the genotypes (Bhole and Patil, 1984). Path analysis is a multivariate analysis, which deals with a closed system of variables, which are linearly related. Dewey and Lu (1959) firstly employed this method to disentangle the direct and indirect influences of components of seed yield. The path coefficient quantifies the inter relationship among different components and their direct and indirect effect on grain yield.

\section{Materials and Methods}

In this present study the experimental material is comprised of 30 biofortified inbred lines of maize which were used to assess correlation and path coefficient analysis for yield contributing traits and grain zinc concentration. The field experiments were conducted in Randomized Block Design (RBD) with three replications during kharif 2017 at Agricultural Research farm, Institute of Agricultural Sciences, BHU Varanasi. The border effect was avoided by planting two border rows. The crop was raised following recommended packages of agronomic practices.
Observations for the pre and post-harvest parameter were recorded on five plants selected at random from each genotype for each replication and averaged. Observations on one biochemical and ten morphological traits viz., Days to $50 \%$ tasseling, Days to 50 $\%$ silking, Width of leaf $(\mathrm{cm})$, ear height $(\mathrm{cm})$, plant height $(\mathrm{cm})$, cob length without husk $(\mathrm{cm})$, cob diameter $(\mathrm{cm}), 100$ seed weight $(\mathrm{g})$, grain yield per plant (g) were recorded. Biochemical analysis for kernel zinc concentration was carried out with diacid (HNO3 and $\mathrm{HClO} 4)$ digestion of seeds followed by atomic absorption spectrometry (AAS) method as per the protocol described by Zarcinas et al., (1987) with some modifications suggested by Singh et al., (2005). Grain Zinc concentration was estimated following AAS based on the Beer Lambert law using the relation Element concentration $(\mathrm{mg} / \mathrm{kg})=$ AAS reading $\times$ dilution factor.

\section{Results and Discussion}

\section{Correlation coefficient analysis}

Genotypic and phenotypic correlation among the eleven quantitative traits of studied maize genotypes was computed and presented in table 1. Tassel length showed positive and significant phenotypic correlation with grain yield per plant and positive and highly significant genotypic correlation with grain yield $(0.2286 \mathrm{P}, 0.2777 \mathrm{G})$. It had positive correlation with GZC (0.0439P, 0.0549G). Ear height showed positive correlation with grain yield (0.1039 P, 0.156G) (Kumar et al., 2006; Jawaharlal et al., 2011; Barua et al., 2017; Gazal et al., 2018). It had positive and significant genotypic correlation with GZC $(0.2335)$ and positive non-significant phenotypic correlation with GZC (0.159). Plant height had positive and non-significant correlation with grain yield $(0.0267 \mathrm{P}$, 0.0632G) (Gazal et al., 2018) and GZC 
(0.0417P, 0.0582G). Cob length without husk showed positive and non-significant correlation with GZC $(0.0114 \mathrm{P}, 0.0373 \mathrm{G})$. It had negative and non- significant correlation with grain yield $(-0.0174 \mathrm{P},-0.178$ G).Cob diameter had positive and significant correlation with grain yield $(0.2353 \mathrm{P}$, 0.3299G) (Kumar et al., 2014) and negative and highly significant correlation with GZC ($0.3491 \mathrm{P},-0.4741 \mathrm{G})$. Hundred seed weight showed positive and non-significant correlation with grain yield $(0.0699 \mathrm{P}$, 0.0859G) (Gazal et al., 2018) while negative and highly significant correlation with GZC ($0.2863 \mathrm{P},-0.3129 \mathrm{G})$. Days to $50 \%$ tasseling showed negative correlation with grain yield ($0.086 \mathrm{P}$ and $-0.330 \mathrm{G}$ ) and also significant and negative correlation with grain zinc concentration (GZC) (-0.2514P, -0.6421G). Days to $50 \%$ silking showed significant negative genetic correlation with grain yield while non-significant phenotypic correlation with grain yield (-0.047 P, -0.298G) (Sumalini and Manjulata, 2012 and Kumar et al., 2014). It had negative correlation with GZC (-0.105P, -0.3473 G). Leaf width showed negative correlation with grain yield $(-0.1016 \mathrm{P},-0.1096$ G) and GZC (-0.0495P, -0.0737G). Zinc concentration showed negative and nonsignificant correlation with grain yield ($0.0386 \mathrm{P},-0.0714 \mathrm{G}$ ) (Banziger and Long, 2000; Brkic et al., 2003 and Chakrabarti et al., 2009). In the present investigation the traits cob diameter, tassel length showed positive and highly significant genotypic correlation and positive and significant phenotypic correlation with yield. Ear height, 100 seed weight and plant height hadpositive correlation with grain yield both at phenotypic and genotypic level, indicating the importance of these traits in selection for yield.

\section{Path coefficient analysis}

Degree and direction of association between various yield attributing traits and grain yield is key to determine suitable selection criteria for both direct and indirect selection through components. The phenotypic path coefficient of different yield attributing traits and grain Zinc concentration was partitioned into direct and indirect effects on grain yield and the data is presented in Table 2. In the present study it was found that cob diameter (0.2933) exhibited the largest direct effect on grain yield per plant followed by tassel length (0.2336), ear height (0.1696),(Kumar et al., 2006; Munwar et al., 2013) days to 50\% silking (0.1608) (Sadaiah et al., 2014) 100 seed weight (0.1086)(Kumar et al., 2006; Sofi \& Rather, 2001) and plant height (0.0371) (Venugopal et al., 2003; Jakhar et al., 2017) contrary to these finding days to $50 \%$ tasseling $(-0.2087)$, leaf width $(-0.1469)$ and cob length without husk (-0.0419) showed negative direct effect on grain yield per plant. Grain zinc concentration has no significant direct or indirect effect on grain yield per plant (Chakrabarti et al., 2009). Among studied traits days to $50 \%$ tasseling showed positive indirect effect on grain yield per plant via grain zinc concentration $(0.0525)$, plant height (0.0207), tassel length (0.0175), leaf width $(0.0029)$ and negative indirect effect via cob length without husk (-0.0525), cob diameter (0.0227). Days to 50\% silking showed indirect effect on grain yield per plant via days to $50 \%$ tasseling (0.1327), cob length without husk (0.0337), 100 seed weight (0.0214) cob diameter (0.0030) and negative indirect effect via plant height (-0.0196), grain zinc concentration (-0.0169). Leaf width showed positive indirect on grain yield per plant via cob length without husk (0.0121), grain zinc concentration (0.0073) and negative indirect effect via tassel length $(-0.0197), 100$ seed weight (-0.0155). Tassel length showed positive indirect effect via leaf width (0.0314), cob length without husk (0.0164) cob diameter (0.0146), grain zinc concentration (0.0103) and negative indirect effect via plant height ($0.0203)$, days to 505 tasseling (-0.0196). 
Table.1 Estimates of Genotypic and phenotypic Correlation co-efficient between yield and its related trait in thirty genotypes of maize

\begin{tabular}{|c|c|c|c|c|c|c|c|c|c|c|c|c|}
\hline Traits & & DTT & DTS & $\mathbf{L W}$ & TL & EH & PH & CLWOH & CD & $100 \mathrm{SW}$ & Zn & GY/P \\
\hline \multirow[t]{2}{*}{ DTT } & $\mathbf{G}$ & 1.0000 & $1.1769 * *$ & -0.0500 & -0.1500 & 0.0176 & $-0.5194 * *$ & -0.0474 & $0.3049 * *$ & $0.2722 * *$ & $-0.6421 * *$ & $-0.3304 * *$ \\
\hline & $\mathbf{P}$ & 1.0000 & $0.8250 * *$ & -0.014 & -0.084 & -0.0013 & -0.099 & $0.2516 *$ & 0.1087 & 0.0821 & $-0.2514 *$ & -0.086 \\
\hline \multirow[t]{2}{*}{ DTS } & $\mathrm{G}$ & & 1.0000 & -0.1490 & -0.1102 & -0.1344 & $-0.3241 * *$ & $0.2153 *$ & 0.2003 & $0.3133 * *$ & $-0.3473^{* *}$ & $-0.2982 * *$ \\
\hline & $\mathrm{P}$ & & 1.0000 & -0.0319 & -0.0836 & -0.0097 & -0.122 & $0.2096 *$ & 0.0189 & 0.1329 & -0.105 & -0.0474 \\
\hline \multirow[t]{2}{*}{$\mathbf{L W}$} & $\mathrm{G}$ & & & 1.0000 & 0.1307 & -0.0022 & $0.0378 * *$ & -0.0798 & 0.1137 & 0.1186 & -0.0737 & -0.1096 \\
\hline & $\mathrm{P}$ & & & 1.0000 & 0.1343 & 0.0116 & 0.0429 & -0.0827 & 0.0843 & 0.1055 & -0.0495 & -0.1016 \\
\hline \multirow[t]{2}{*}{ TL } & $\mathrm{G}$ & & & & 1.0000 & -0.0169 & -0.1055 & $0.3561 * *$ & 0.0163 & 0.0002 & 0.0549 & $0.2777 * *$ \\
\hline & $\mathrm{P}$ & & & & 1.0000 & 0.0117 & -0.0869 & 0.0704 & 0.0626 & -0.0023 & 0.0439 & 0.2286 \\
\hline \multirow[t]{2}{*}{ EH } & $\mathrm{G}$ & & & & & 1.0000 & -0.3706 & $-0.3751 * *$ & $0.2543^{*}$ & 0.1733 & $0.2335^{*}$ & 0.156 \\
\hline & $\mathrm{P}$ & & & & & 1.0000 & $-0.2349 *$ & -0.1338 & 0.1765 & 0.1512 & 0.159 & 0.1039 \\
\hline \multirow[t]{2}{*}{ PH } & $\mathrm{G}$ & & & & & & 1.0000 & $-0.5668 * *$ & -0.1725 & 0.0167 & 0.0582 & 0.0632 \\
\hline & $\mathrm{P}$ & & & & & & 1.0000 & -0.135 & -0.0921 & 0.0332 & 0.0417 & 0.0267 \\
\hline \multirow[t]{2}{*}{ CLWOH } & $\mathrm{G}$ & & & & & & & 1.0000 & $-0.4258 * *$ & $-0.2436^{*}$ & 0.0373 & -0.1787 \\
\hline & $\mathrm{P}$ & & & & & & & 1.0000 & -0.0517 & -0.1122 & 0.0114 & -0.0174 \\
\hline \multirow[t]{2}{*}{ CD } & G & & & & & & & & 1.0000 & 0.1178 & $-0.4741 * *$ & $0.3299 * *$ \\
\hline & $\mathrm{P}$ & & & & & & & & 1.0000 & 0.0698 & $-0.3491 * *$ & 0.2352 \\
\hline \multirow[t]{2}{*}{$100 \mathrm{SW}$} & G & & & & & & & & & 1.0000 & $-0.3129 * *$ & 0.0859 \\
\hline & $\mathrm{P}$ & & & & & & & & & 1.0000 & $-0.2863 * *$ & 0.0699 \\
\hline \multirow[t]{2}{*}{ Zn } & $\mathrm{G}$ & & & & & & & & & & 1.0000 & -0.0714 \\
\hline & $\mathrm{P}$ & & & & & & & & & & 1.0000 & -0.0386 \\
\hline
\end{tabular}

*and ** Significant at 5\% and 1\% level of significance, respectively. Where PH $(\mathrm{cm})=$ plant height, DTT $(50 \%)=$ days to $50 \%$ tasseling, DTS $(50 \%)=$ days to $50 \%$ silking, $\mathrm{LW}(\mathrm{cm})=$ leaf width, $\mathrm{EH}(\mathrm{cm})=$ ear height, $\mathrm{TL}(\mathrm{cm})=$ tassel length, $\mathrm{CLWOH}(\mathrm{cm})=$ cob length without husk, $\mathrm{CD}(\mathrm{cm})=\mathrm{cob}$ diameter, $100 \mathrm{SW}(\mathrm{g})$ $=100$ seed weight, $\mathrm{Y} / \mathrm{P}=$ yield per plant, $\mathrm{Zn}(\mathrm{mg} / \mathrm{kg})=$ Zinc content . 
Table.2 Estimates of Phenotypic path matrix of direct (diagonal) and indirect effects of yields components on yield per plant in thirty maize genotypes

\begin{tabular}{|c|c|c|c|c|c|c|c|c|c|c|c|}
\hline Character & DTT & DTS & $\mathbf{L W}$ & TL & EH & PH & CLWOH & CD & $100 \mathrm{SW}$ & Zn & GY/P \\
\hline DTT & -0.2087 & -0.1722 & 0.0029 & 0.0175 & 0.0003 & 0.0207 & -0.0525 & -0.0227 & -0.0171 & 0.0525 & -0.086 \\
\hline DTS & 0.1327 & 0.1608 & -0.0051 & -0.0134 & -0.0016 & -0.0196 & 0.0337 & 0.0030 & 0.0214 & -0.0169 & -0.0474 \\
\hline LW & 0.0020 & 0.0047 & -0.1469 & -0.0197 & -0.0017 & -0.0063 & 0.0121 & -0.0124 & -0.0155 & 0.0073 & -0.1016 \\
\hline TL & -0.0196 & -0.0195 & 0.0314 & 0.2336 & 0.0027 & -0.0203 & 0.0164 & 0.0146 & -0.0005 & 0.0103 & 0.2286 \\
\hline EH & 0.0002 & 0.0016 & -0.0020 & -0.0020 & 0.1696 & 0.0398 & 0.0227 & -0.0299 & 0.0256 & -0.0270 & 0.1039 \\
\hline PH & -0.0037 & -0.0045 & 0.0016 & -0.0032 & -0.0087 & 0.0371 & -0.0050 & -0.0034 & 0.0012 & 0.0015 & 0.0267 \\
\hline CLWOH & -0.0106 & -0.0088 & 0.0035 & -0.0030 & 0.0056 & 0.0057 & -0.0419 & 0.0022 & 0.0047 & -0.0005 & -0.0174 \\
\hline CD & 0.0319 & 0.0056 & 0.0247 & 0.0184 & 0.0518 & -0.0270 & -0.0152 & 0.2933 & 0.0205 & -0.1024 & 0.2352 \\
\hline $100 \mathrm{SW}$ & -0.0089 & -0.0144 & -0.0115 & 0.0003 & 0.0164 & -0.0036 & 0.0122 & -0.0076 & 0.1086 & 0.0311 & 0.0699 \\
\hline $\mathbf{Z n}$ & -0.0014 & -0.0006 & -0.0003 & 0.0002 & 0.0009 & 0.0002 & 0.0001 & -0.0019 & -0.0016 & 0.0055 & -0.0386 \\
\hline
\end{tabular}


Ear height showed positive indirect effect via plant height (0.0314), 100 seed weight (0.0256), cob length without husk (0.0227) and negative indirect effect via cob diameter $(-0.0299)$ and grain zinc concentration (0.0270). Cob diameter showed positive indirect effect via ear height (0.0518), days to $50 \%$ tasseling (0.0319), leaf width (0.0247), 100 seed weight (0.0205) and negative indirect effect via grain zinc concentration (0.1024) and cob length without husk (0.0152). 100 seed weight showed positive indirect effect via grain zinc concentration (0.0311), ear height (0.0164) and negative indirect effect via days to $50 \%$ tasseling ($0.0144)$ and leaf width $(-0.0115)$.

Tassel length, ear height and plant height was positively and significantly associated with grain yield per plant and grain zinc concentration which indicates the importance of these traits in selection for higher yield and grain zinc concentration. Cob length show positive association with GZC but negative association with grain yield as against of cob diameter and 100 seed weight, which had positive association with grain yield but a negative association with GZC. Days to $50 \%$ tasselling and silking and leaf width has negative association with grain yield and GZC while GZC itself had a negative association with grain yield. Path analysis studies showed that cob diameter, tassel length, ear height, days to $50 \%$ silking, 100 seed weight and plant height had direct positive effect on grain yield per plant, contrary to these finding days to $50 \%$ tasselling, leaf width and cob length without husk showed negative direct effect on grain yield per plant.

\section{Acknowledgement}

We should duly acknowledge Institute of Agricultural Sciences, BHU for financial support. We should also pay our special gratitude to Dr. S.K. Singh Professor Genetics and Plant Breeding, BHU, Varanasi and Dr. Satish Kumar Singh Asst. Professor Genetics and Plant Breeding, Dr. RPCAU, Pusa for their valuable guidance and generous help for the completion of this work.

\section{References}

Banziger, M. and Long, J. 2000. The potential for increasing the iron and zinc density of maize through plant breeding, Food and Nutrition Bulletin. 21(4): 397-400.

Barua, N. S., Chaudhary, V. P. and Hazarika, G. N. 2017. Genetic variability and correlation studies for morphological traits in maize (Zea mays L.) genotypes. Indian Research and Journal of Genetics and Biotechnology. 9(1): 38-48.

Bhole, G. R. and Patil, R. C. 1984. Genotypic and phenotypic correlations in maize, Journal of Maharashtra Agricultural Universities. 9(3): 250-251.

Brkic, I., Simic, D., Zdunic, Z., Jambrovic, A., Ledencan, T., Kovacevic, V. and Kadar, I. 2003. Combining abilities of Corn-Belt inbred lines of maize for mineral contentin grain, Maydica. 48(4): 293-297

Chakraborti, M., Hossain, F., Kumar, R., Gupta, H. S. and Prasanna, B. M. 2009. Genetic Evaluation of Grain Yield and Kernel Micronutrient Traits in Maize, Pusa Agri Science. 32(2): 11-16.

Cortez A, Wild-Altamirano C. Contributions to the lime treated corn flour technology, In: Nutritional Improvement of Maize, Eds. Bressani, R., Braham, J.E. and Behar, INCAP pub. L4, 1972, 99-106.

Dewey, D. R. and Lu, H. K. 1959. A correlation and path coefficient analysis of components of created wheat grass and seed production, Agronomy Journal. 51(9): 515-518.

Gazal, A., Dar, Z. A., Lone, A. A., Yousuf, N. and Gulzar, S. 2018. Studies on Maize Yield under Drought Using Correlation and Path Coefficient Analysis, International Journal of Current 
Microbiology and Applied Sciences. 7(1): 516-521.

Jakhar, D. S., Singh, R. and Kumar, A. 2017. Studies on path coefficient analysis in maize (Zea mays L.) for grain yield and its attributes, International Journal of Current Microbiology and Applied Sciences. 6(4): 2851-2856.

Jawaharlal, J., Reddy, G. L. and Kumar, R. S. 2011. Genetic variability and character association studies in maize, Agricultural Science Digest. 31(3): 173-177.

Khatab, I.A., Farid M.A. and Kumamaru, T.2016. Genetic diversity associated with heading date in some rice (Oryza sativa L.) genotypes using microsatellite markers. Journal of Environmental \& Agricultural Sciences. 6: 58-63.

Kumar, S., Shahi, J. P., Singh, J. and Singh, S. P. 2006. Correlation and path analyis in early generation inbreds of maize (Zea mays L.), Crop Improvement. 33(4): 156160.

Kumar, V., Singh, S. K., Bhati, P. K., Sharma, A. Sharma, S. K. and Mahajan, V. 2014. Correlation, Path and Genetic Diversity Analysis in Maize (Zea mays L.), Journal of Environment and Ecology. 33(2A): 971-975.

Munawar, M., Shahbaz, M., Hammad, G. and Yasir, M. 2013. Correlation and path analysis of grain yield components in exotic maize (Zea mays L.) hybrids, International Journal of Sciences: Basic and Applied Research. 12(1): 22-27.

Rafiq, C. M., Rafique, M. and Altaf, A. H. M. 2010. Studies on heritability, correlation and path analysis in maize (Zea mays L.),
Journal of Agriculture Research, (Lahore). 48(1): 35-38.

Sadaiah, K., Reddy, V. N. and Kumar, S. S. 2013. Correlation Studies for Yield and Yield Contributing Characters in Sweetcorn (Zea mays L.), International Journal of Agriculture Innovations and Research. 2(2): 145-148.

Singh D, Chonkar PK, Dwivedi BS. Manual on Soil, Plant and Water Analysis. Westville Publishers, New Delhi.2005.

Sofi, P. and Rather, A. G. 2007. Studies on genetic variability, correlation and path analysis in maize (Zea mays L.). University of Agriculture Sciences and Technology of Kashmir, Shalimar.

Sumalini, K. and Manjulatha, G. 2012. Broad sense heritability, Correlation, Maize, Path coefficient analysis, Maize Journal. 1(2): 97- 01.

Venugopal, M., Ansari, N.A. and Rajanikanth, T. 2003. Correlation and path analysis in maize (Zea mays L.), Crop Research. 25(3): 525-529

White PJ, Broadley MR. Biofortification of crops with seven mineral elements often lacking in human diets iron, zinc, copper, calcium, magnesium, selenium and iodine. New Phyto. 2008; 182(1):49-84.

Zarcinas BA, Cartwright B, Spouncer LR. Nitric acid digestion and multi element analysis of plant material by inductively coupled plasma spectrometry. Commun Soil Sci Plant Analysis, 1987; 18: 131146.

Zimmermann MB, Hurrell RF. Improving iron, zinc and vitamin A nutrition through plant biotechnology. Current Opinion in Biotechnology. 2002; 13(2): 142-145.

\section{How to cite this article:}

Priyanka Jaiswal, Banshidhar and Rajesh Singh. 2019. Correlation and Path Coefficient Analysis for Yield Contributing Traitsand Grain Zinc Concentration in Biofortified Inbred Lines of Maize (Zea mays L.). Int.J.Curr.Microbiol.App.Sci. 8(07): 1358-1364. doi: https://doi.org/10.20546/ijcmas.2019.807.162 